ритма секретопродуцирующих клеток эпифиза. Фотопериодическая дезинтеграция сопровождается распространением процесса, кроме СХЯ и шишковидной железы, и на нейроны гиппокампа.

Ключевые слова: шишковидная железа, фотопериод, почки, мелатонин, эпиталон.

\title{
TIME ORGANIZATION OF PHYSIOLOGICAL FUNCTIONS IN MAMMALS. CEREBRAL STRUCTURES INVOLVEMENT
}

\section{R.Ye. Bulyk, I.V. Herush, V.P. Pishak, Y.Y. Rohovyi}

\begin{abstract}
The results of five year research concerning the mechanism providing circadian rhythms of physiological functions of organs, in particular the kidneys, are presented in the paper. It was proved by light optical, electron microscopy, biochemical and immunohistochemical methods that structures of the organs under the study as well as their functions are strongly subordinate to the duration of the photoperiod. Depression of the pineal body activity (24 hour lighting) causes desynchronization in the structure of suprachiasmatic nucleus $(\mathrm{SCN})$ neurons and in protein c-Fos synthesis. Disturbance of the diurnal rhythm of the SCN pacemaker and of melatonin synthesis is conditioned by the change in the rhythm of epiphysis secretory cells. Besides the SCN and the pineal gland, the hippocampus neurons are involved in the photoperiod disintegration.
\end{abstract}

Key words: pineal gland, photoperiod, kidneys, melatonin, epitalon.

Bukovinian State Medical University (Chernivtsi)

Рецензент - проф. Г.І. Ходоровський

Buk. Med. Herald. - 2014. - Vol. 18, № 1 (69). - P. 144-147

Надійшла до редакції 14.01.2014 року

(C) Р.Є. Булик, І.В. Геруш, В.П. Пішак, Ю.Є. Роговий, 2014

УДК 616-071/.071/.079

І.А. Плеш, Г.І. Кшановська, О.Й. Хомко, Л.Д. Борейко, О.В. Макарова СУЧАСНІ МОЖЛИВОСТІ КЛІНІЧНОЇ ЛАБОРАТОРНОЇ ДІАГНОСТИКИ

Буковинський державний медичний університет, м. Чернівці

Резюме. У статті висвітлено сучасні можливості клінічної лабораторної діагностики, розвиток нових розділів лабораторної медицини - протеоміки та геноміки, виявлення маркерів пухлин, високочутливих молекулярно-генетичних методик та важливість вивчення можливостей клінічної лабораторної діагностики на

Вступ. Демографічний стан населення України супроводжується зростанням смертності, особливо серед осіб працездатного віку, його значною інвалідизацією, що викликає все більше занепокоєння. Тому проблема здоров'я народу повинна бути пріоритетною в державі й може бути вирішена, у першу чергу, за рахунок покращання підготовки висококваліфікованих медичних фахівців у вищих навчальних закладах. Діагностика захворювань, оцінка їх перебігу, прогноз, вибір правильної тактики лікування з подальшим поліпшенням якості життя пацієнта не може обходитися без використання лабораторних методів дослідження $[2,5]$. Лікар повинен бути впевненим у достовірності проведеного аналізу, тому особливу роль відіграє якість виконаних досліджень, що може бути забезпечено тільки фахівцями високого рівня.

Ступінь розвитку лабораторної служби, 3 точки зору компетентних спеціалістів, у тому числі й експертів ВООЗ, стає важливим рейтинговим критерієм ефективного лікування. За дани- старших курсах медичних університетів майбутніх лікарів різних спеціальностей.

Ключові слова: лікарський моніторинг, діагностичні тести, вища медична освіта, медичний лаборант, бакалавр.

ми експертів ВОО3, обсяг лабораторних обстежень становить не менше $60 \%$ від загального числа обстежень, а їх кількість та якість за кожних п'ять років зростає у два рази [2]. Результати лабораторних обстежень отримують дійсну вартість тільки при цілеспрямованому призначенні і коректній оцінці результатів, при застосуванні сучасної апаратури і якісних діагностикумів, асортимент яких щороку розширюється, а лікарі не завжди володіють інформацією про їх можливості. Для інформування медичних працівників необхідно організувати цикл лекцій про можливості сучасних клінічних лабораторій. Складність ситуації полягає ще в тому, що навчальними планами вищих медичних закладів (академій, університетів) не передбачено вивчення можливостей клінічної лабораторної діагностики на старших курсах майбутніх лікарів різних спеціальностей, на курсах удосконалення та передатестаційних циклах післядипломної освіти.

Дослідженням структури, складу і властивостей різних біологічних матеріалів займаються 
субдисципліни клінічної лабораторної діагностики (патогістологія, цитологія, мікробіологія, паразитологія, імунологія, біохімія та ін.). В останні роки швидко розвиваються нові аналітичні методи (полімеразна ланцюгова реакція, фенотипування клітин і цитоморфологічні дослідження, імунохроматологічні експрес-методи та ін.)

В основу сучасних методів клінічної лабораторної діагностики покладено багаторічний досвід лікарів-лаборантів різного профілю (клініцистів, біохіміків, імунологів, бактеріологів та ін.). Досягнення клінічної медицини, лабораторної діагностики та організації медичної допомоги може полегшити завдання лікарів 3 оцінки (тлумачення) результатів клінічно-лабораторних досліджень, надати необхідний обсяг лабораторних досліджень при захворюваннях, які найчастіше трапляються в клініках.

Постійна тісна співпраця лікаря-клініциста i лікаря-лаборанта $є$ тим чинником, що позитивно впливає на результативність діагностичного пошуку, а в остаточному підсумку - i на ефективність лікування хворого.

У практиці медичних лабораторій широко використовуються такі методи, як спектрофотометрія, нефелометрія, турбідиметрія, флуориметрія, поляриметрія, радіоімунний, імуноферментний, флуоресцентний і хемілюмінісцентний аналізи та ін. $[4,6]$. Біохімічні аналізатори можуть виконувати до 1000 досліджень за годину .

За останні роки досягнуто значного прогресу в розвитку молекулярної біології, дослідженні геному, вивченні ролі регуляторних факторів (кініни, фактори росту, цитокініни, специфічні білки тощо), що потребує поглиблення рівня знань студентів [3]. Значні досягнення в клінічній біохімії дають змогу на основі сучасних методів дослідження використати найновіше обладнання для поліпшення діагностування захворювань та їх прогнозування.

Визначення в біологічних рідинах організму гормонів, імуноглобулінів, онкомаркерів, регуляторних пептидів призводить до поглибленого розуміння біохімічних процесів у нормі та при різних патологічних станах організму [4].

Сучасні високочутливі методи лабораторної діагностики окремих захворювань навіть перевершують за інформативністю інструментальні методи і входять до переліку стандартних досліджень, необхідних для верифікації діагнозу. Важливим розділом лабораторної медицини стає лікарський моніторинг. Інтенсивно розвиваються нові розділи лабораторної медицини - протеоміка та геноміка, виявлення маркерів пухлин. Вивченням і розшифровкою генетичної інформації займається геноміка [7]. Дані іiі досліджень дозволили нам приступити до вивчення структури рибонуклеїнової кислоти (РНК) і білка, які знаходяться вже «за» геномом. Протеоміка займається інвентаризацією білків, тобто визначенням сукупності білків у певних зразках і одночасно порівняння цих комплексів 3 іншими зразками.
Найвищою чутливістю характеризуються молекулярно-генетичні методики. Так, метод полімеразно-ланцюгової реакції ДНК плазми крові дозволяє виявити пухлинне вогнище розміром до $0,01 \mathrm{~cm}^{3}[1]$. Ці методи вже знаходять широке застосування в моніторингу, на ранньому доклінічному виявленні рецидивів і контролі ефективності терапії злоякісних новоутворень. Важливим розділом лабораторної медицини стають методи експрес-діагностики, так звані приліжкові тести (point care). Шляхом впровадження досягнень фундаментальних досліджень i iнформаційних технологій лабораторна діагностика прискорює розвиток клінічної медицини та ії ефективність.

Якщо діагноз заснований на лабораторних даних, лікар повинен бути впевнений у надійності методу і в якості виконання дослідження. При цьому під якістю розуміють наявність впевненості в тому, що правильно та своєчасно призначений діагностичний тест, небхідний для пацієнта, виконаний на достатньому аналітичному рівні та супроводжується необхідною інформацією для його інтерпретації. Важливою проблемою для клініциста є вибір найбільш доцільного діагностичного тесту, який залежить від мети проведення дослідження (скринінговий, діагностичний, диференційно-діагностичний, моніторинг ефективності лікування та ін.). Основою для встановлення необхідної точності стає біологічна варіація того чи іншого лабораторного параметра.

Принципово важливим є питання медичної важливості отриманих результатів і необхідності підвищення ролі лікаря клінічної лабораторної діагностики у формуванні діагностичного алгоритму та інтерпретації результатів. У зв'язку 3 цим, не можна недооцінювати значимість дієвого співробітництва клініциста і фахівця з лабораторної медицини - у клінічній практиці. Сьогодні актуальні сказані, багато років тому, слова академіка О.М. Тареєва: «Особливо істотним я вважаю знання лікарем істинної цінності лабораторних досліджень, правильну і глибоку інтерпретацію одержуваних відповідей. Без цього навіть чудово обладнана лабораторія працює, певною мірою, даремно ... ». Очевидно, що клініцистам вкрай необхідні знання основ лабораторної діагностики та чітке розуміння доцільності призначуваних досліджень, а спеціаліст 3 лабораторної медицини, у свою чергу, обов'язково повинен володіти клінічним мисленням і вдосконалювати його.

Проведення лабораторних досліджень має сенс тільки при їх відповідності своєму призначенню. Це виконується, якщо лабораторні дослідження відповідають клінічній задачі, правильно проведений відбір зразків та їх транспортування в лабораторію, дослідження виконані аналітично грамотно, а результати досліджень фахово інтерпретовані .

Враховуючи реальну ситуацію в охороні здоров'я населення України, у Буковинському державному медичному університеті здійснюється підготовка фахівців за спеціальністю "Лабо- 
раторна діагностика" (освітньо-кваліфікаційний рівень (ОКР) - “бакалавр”), за уніфікованою освітньо-професійною програмою, затвердженою MO3 України, на основі якої розроблені робочі програми та навчально-методичні матеріали 3 дисципліни “Клінічна лабораторна діагностика".

Кожний лаборант-бакалавр оволодіває навиками загальноклінічних, гематологічних, біохімічних, імунологічних, бактеріоскопічних досліджень.

Під час навчання на кафедрі догляду за хворими та вищої медсестринської освіти лаборантибакалаври відвідують лекції та практичні заняття, на яких проводять клінічно-лабораторні дослідження, необхідні для діагностики, оцінки перебігу захворювань та їх прогнозу, ефективності лікування, а також аналізу результатів отриманих даних.

У рамках співпраці Буковинського державного медичного університету та Чернівецького обласного діагностичного центру, де проводяться майстер-класи для студентів старших курсів за спеціальністю «Лабораторна діагностика» (ОКР «бакалавр»), на яких демонструються лікарямилаборантами центру можливості лабораторної діагностики на сучасних гематологічних, біохімічних, імунологічних аналізаторах. Це дає можливість ознайомити студентів із реальними можливостями сучасної медичної лабораторії, перспективами розвитку лабораторної діагностики, важливістю цієї спеціальності в галузі медицини і поставити перед собою мету для найкращого опанування майбутньої професії.

На практичних заняттях та під час проходження виробничої практики студенти освоюють медичну апаратуру та засвоюють сучасні методики обстежень: крові, сечі, калу, мокротиння, шлункового та дуоденального вмісту, ліквору, випітних рідин, сім'яної рідини, проводять гінекологічні, цитологічні дослідження та інші. Виконуючи науково-дослідну роботу, студенти розширюють свої пізнання в галузі лабораторної діагностики, набувають теоретичних знань, необхідних навичок та вмінь.

Більшість практичних занять проводиться на базах спеціалізованих стаціонарів м.Чернівці та клінічно-діагностичних лабораторій: Обласної комунальної установи (ОКУ) “Лікарня швидкої медичної допомоги” (клінічна, біохімічна та бактеріологічна лабораторії), Головного управління
Держсанепідслужби в Чернівецькій області (вірусологічному, токсикологічному, охорони навколишнього середовища, гігієни харчування та комунальної гігієни підрозділах). Це сприяє ознайомленню студентів зі специфікою роботи в лабораторіях різного профілю.

Випускники даної спеціальності мають право в подальшому працювати на посадах лаборантів клінічно-діагностичних, біохімічних, бактеріологічних, паразитологічних, імунологічних, генетичних, цитологічних, судово-медичних, санітарно-епідеміологічних лабораторій.

\section{Висновок}

Таким чином, на сучасному рівні розвитку медицини лабораторна діагностика набуває все більш важливого практичного значення, внаслідок чого зростає попит на фахівців даної професії Відкривається все більше приватних медичних лабораторій, оснащених сучасною апаратурою, які потребують багато висококваліфікованих спеціалістів. Тому першочерговим завданням вищої медичної школи $є$ підготовка висококваліфікованих спеціалістів 3 лабораторної діагностики. Якісна підготовка кадрів у Буковинському державному медичному університеті зі спеціальності «Лабораторна діагностика» сприяє збереженню здоров'я народу України.

\section{Література}

1. Методы клинических исследований / Под ред. проф В.С. Камышникова. - М.: МЕДпресс-информ, 2011. $751 \mathrm{c}$.

2. Клінічна біохімія. Практикум (3-тє видання) / [Лаповець Л.Є., Луцик Б.Д., Порохнавець Л.Є. та ін.]. - Львів, 2008. -230 с.

3. Біохімічні показники в нормі і при патології. Навчальний довідник / [Д.П. Бойків, Т.I. Бондарчук, О.Л.Іванків та ін.]; за ред. О.Я.Склярова. - К.: Медицина, 2007. $-320 \mathrm{c}$.

4. Горячковський О.М Клінічна біохімія в лабораторній діагностиці: Довідковий посібник / О.М. Горячковський.- Вид. 3-тє, вип. і доп. - Одеса: Екологія, 2005. $616 \mathrm{c}$.

5. Сучасний стан здоров'я народу та напрямки його покращання в Україні. Аналітично-статистичний посібник / за ред. чл.-кор. АМН України, проф., д.мед.н. В.М. Коваленка. - К., 2005. - 140 с.

6. Справочник по лабораторным методам исследования / Под ред. Л.А. Даниловой. - СПб.: Питер, 2003. $736 \mathrm{c}$.

7. Кропивницький А.В Післягеномна ера. Протеоміка нові горизонти в фармакології / А.В. Кропивницький // День. - 2004. - № 57. - С. 20-28.

\section{СОВРЕМЕННЫЕ ВОЗМОЖНОСТИ КЛИНИЧЕСКОЙ ЛАБОРАТОРНОЙ ДИАГНОСТИКИ}

\section{И.А. Плеш, А.И. Кшановская, О.И. Хомко, Л.Д. Борейко, Е.В. Макарова}

Резюме. В статье представлены возможности клинической лабораторной диагностики, розвитие новых разделов лабораторной медицины - протеомики и геномики, выявление маркеров опухолей, сверхчуствительных молекулярно-генетических методик и важность изучения возможности клинической лабораторной диагностики на старших курсах будущих врачей разных специальностей .

Ключевые слова: врачебный мониторинг, диагностические тесты, высшее медицинское образование, медицинский лаборант, бакалавр. 


\section{“MODERN POSSIBILITIES OF CLINICAL LABORATORY DIAGNOSTICS”}

\section{I.A. Plesh, A.I. Kshanovska, O.Y. Khomko, L.D. Boreiko, O.V. Makarova}

Abstract: This article presents the possibilities of clinical laboratory diagnostics, development of new sections of laboratory medicine, such as proteomics and genomics, determination of tumor's markers, supersensitive molecular genetics techniques and the importance of studying of the possibilities of clinical laboratory diagnostics on the last courses of the future doctors of different specialities.

Key words: medical monitoring, diagnostics tests, higher medical education, Medical laboratory assistant, Bachelor.

Bukovinian State Medical University (Chernivtsi)

Рецензент - проф. О.І. Федів

Buk. Med. Herald. - 2014. - Vol. 18, № 1 (69). - P. 147-150

Надійшла до редакції 11.12.2013 року

( І.А. Плеш, Г.І. Кшановська, О.Й. Хомко, Л.Д. Борейко, О.В. Макарова, 2014 